\title{
Effects of resveratrol on cariogenic virulence properties of Streptococcus mutans
}

\author{
Jinheng Li, Tiantian Wu, Weiwei Peng and Yaqin Zhu*
}

\begin{abstract}
Background: Streptococcus mutans is the principal etiological agent of human dental caries. The major virulence factors of S. mutans are acid production, acid tolerance, extracellular polysaccharide (EPS) synthesis and biofilm formation. The aim of this study is to evaluate the effect of resveratrol, a natural compound, on virulence properties of S. mutans.

Results: Resveratrol at sub-MIC levels significantly decreased acid production and acid tolerance, inhibited synthesis of water-soluble polysaccharide and water-insoluble polysaccharide, compromised biofilm formation. Related virulence gene expression (Idh, relA, gtfC, comDE) was down-regulated with increasing concentrations of resveratrol.
\end{abstract}

Conclusions: Resveratrol has an inhibitory effect on S. mutans cariogenic virulence properties and it represents a promising anticariogenic agent.

Keywords: Resveratrol, Streptococcus mutans, Acidogenicity, Aciduricity, Extracellular polysaccharide, Biofilm

\section{Background}

Dental caries is a multi-factorial infectious chronic disease which causes demineralization and progressive destruction of the dental enamel by specific bacteria and their virulence products [1]. Streptococcus mutans, a Gram-positive oral bacterium, has long been implicated as the principal etiological agent of human dental caries [2]. The major virulence factors of S. mutans are its ability to produce organic acids through metabolism of dietary carbohydrates (acidogenecity) and to withstand and survive under low $\mathrm{pH}$ environment (aciduricity) [3, 4]. One of the most important virulence factors is its ability to produce glucosyltransferases (GTFs) to catalyze synthesis of extracellular polysaccharides (EPS) from

\footnotetext{
* Correspondence: zyq1590@163.com

Department of General Dentistry, College of Stomatology, Shanghai Ninth People's Hospital, Shanghai Jiao Tong University School of Medicine,

National Clinical Research Center for Oral Diseases, Shanghai Key Laboratory of Stomatology \& Shanghai Research Institute of Stomatology, 639 Zhi Zao Ju Road, Shanghai 200011, China
}

sucrose, which allows bacteria to effectively colonize on the tooth surfaces and contribute to the formation of highly cariogenic plaque biofilms [5, 6]. Therefore, inhibition of cariogenic virulence of $S$. mutans could be an effective way to prevent and control dental caries.

Fluoride plays an important role in preventing the prevalence and severity of dental caries [7]. It is a well-known cariostatic agent via the inhibition of demineralization and the enhancement of remineralization and the inhibition of bacterial activity such as acid production, acid tolerance and EPS formation [8]. However, its excessive use results in adverse effects like fluorosis which limited fluoride using for public health in many countries $[9,10]$. Therefore, the development of an alternative cariostatic agent with minimal side effects is urgent.

Natural products are major sources of attractive and effective therapeutic agents for the discovery and development of new drugs throughout human history. They have a wide range of structurally biochemical specificities and

(c) The Author(s). 2020 Open Access This article is licensed under a Creative Commons Attribution 4.0 International License, which permits use, sharing, adaptation, distribution and reproduction in any medium or format, as long as you give appropriate credit to the original author(s) and the source, provide a link to the Creative Commons licence, and indicate if changes were made. The images or other third party material in this article are included in the article's Creative Commons licence, unless indicated otherwise in a credit line to the material. If material is not included in the article's Creative Commons licence and your intended use is not permitted by statutory regulation or exceeds the permitted use, you will need to obtain permission directly from the copyright holder. To view a copy of this licence, visit http://creativecommons.org/licenses/by/4.0/ The Creative Commons Public Domain Dedication waiver (http://creativecommons.org/publicdomain/zero/1.0/) applies to the data made available in this article, unless otherwise stated in a credit line to the data. 
can divided into phenolic acids, anthraquinones, flavonoids, stilbenes, tannins, terpenoids and alkaloids [11, 12]. Recently, there is an increasing interest in natural products as cariostatic agents for promising novel anticariogenic strategy. A number of compounds, such as epicatechin, apigenin, oolong tea, have shown their efficacy anti-caries activity against oral microbial pathogens $S$. mutans [13-15].

Resveratrol (3,5,4' -trihydroxy-trans-stilbene) is a natural compound found in many plant extracts, including grapes, peanuts, cranberries and Polygonum cuspidatums. It is a member of the stilbene family and a precursor of other stilbenes such as viniferins and pterostilbene (trans-3,5-dimethoxy-40-hydroxystilbene). Resveratrol is known to have numerous biological functions such as antimicrobial activity, antiviral, antioxidant, antiinflammatory, and anticancer $[16,17]$. But there is little work about its anti-cariogenic properties.

Therefore, in the present study, we investigated the effect of resveratrol on S. mutans anti-cariogenic properties. We focused on the effects of resveratrol on acid production, acid tolerance, extracellular polysaccharide synthesis, biofilm formation and structure, virulence gene expression. This research would help to offer the possibility of natural product as novel anti-cariogenic agent to advance the caries progression investigation and prevent dental diseases efficiently.

\section{Results}

\section{Growth curve assay and MIC}

We evaluated the effects of resveratrol with different concentrations on growth rate of $S$. mutans by growth curve assay. It was observed that in comparison to the vehicle control, the bacterial growth was significantly inhibited with $800 \mu \mathrm{g} / \mathrm{mL}$ resveratrol treatment (Fig. 1). The MIC of resveratrol against S. mutans was $800 \mu \mathrm{g} /$ $\mathrm{mL}$. However, there was no obvious difference in the growth curve with resveratrol concentrations below $400 \mu \mathrm{g} / \mathrm{mL}$.

\section{Acid production assay}

We determined the effects of resveratrol at sub-MIC levels on acid production through the glycolytic $\mathrm{pH}$ drop assay and LDH assay. As shown in Fig. 2, the $\mathrm{pH}$ value (at 10, 20, 30, 40, 50, 60, 75, 90, 105 and 120 min incubation period) at 50,100, 200 and $400 \mu \mathrm{g} / \mathrm{mL}$ resveratrol were significantly different from those of the vehicle control $(P<0.05)$. In general, resveratrol reduced the initial rate of the $\mathrm{pH}$ drop (the amount of $\mathrm{pH}$ drop/min) at 50, 100, 200 and $400 \mu \mathrm{g} / \mathrm{mL}$, compared with the vehicle control $(P<0.05)$. The final $\mathrm{pH}$ values (at $120 \mathrm{~min}$ incubation) at 50,100, 200 and $400 \mu \mathrm{g} / \mathrm{mL}$ resveratrol were significantly different from that of the vehicle control $(\mathrm{P}<0.05)$. As shown in Fig. 3, LDH activity was decreased from $88.2 \pm 2.1 \%$ at $50 \mu \mathrm{g} / \mathrm{mL}$ to $66.7 \pm 0.6 \%$ at $400 \mu \mathrm{g} / \mathrm{mL}$, resveratrol significantly reduced LHD activity at 50,100, 200 and $400 \mu \mathrm{g} / \mathrm{mL}$ compared with the control $(P<0.05)$, which were consistent with the results of the glycolytic $\mathrm{pH}$ drop assay.

\section{Acid tolerance assay}

Resveratrol at sub-MIC levels can also inhibit S. mutans acid tolerance. As shown in Fig. 4a, The survive rate of S. mutans at pH5.0 was significantly decreased after

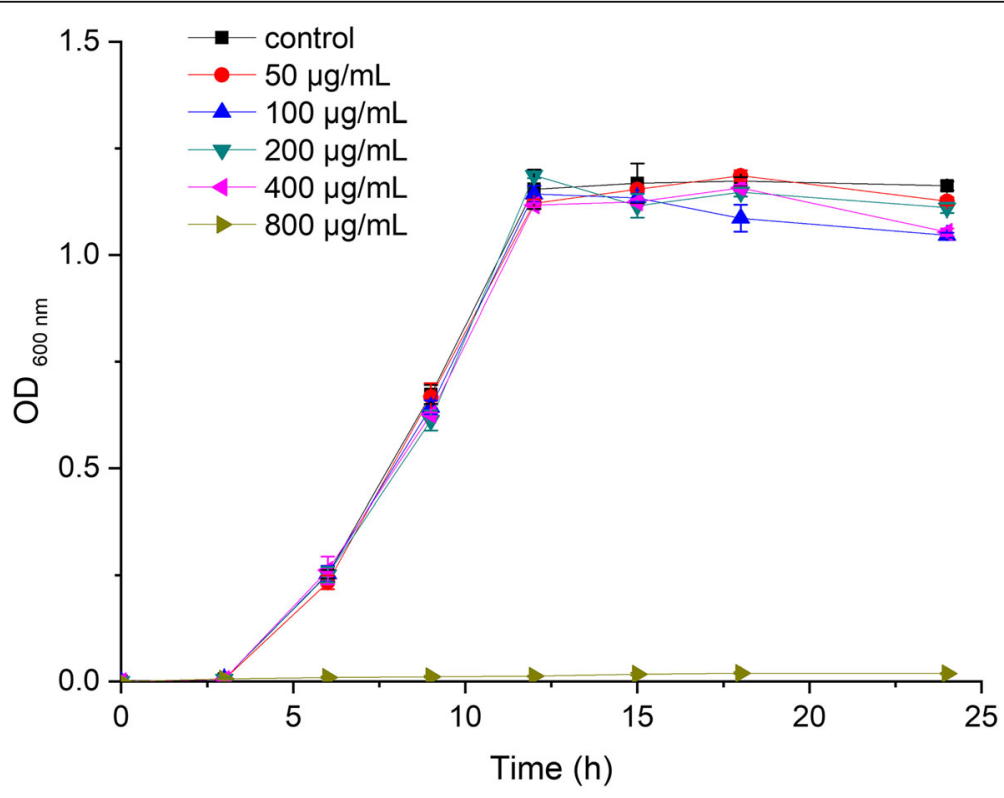

Fig. 1 Growth curve of S.mutans with different concentrations of resveratrol 


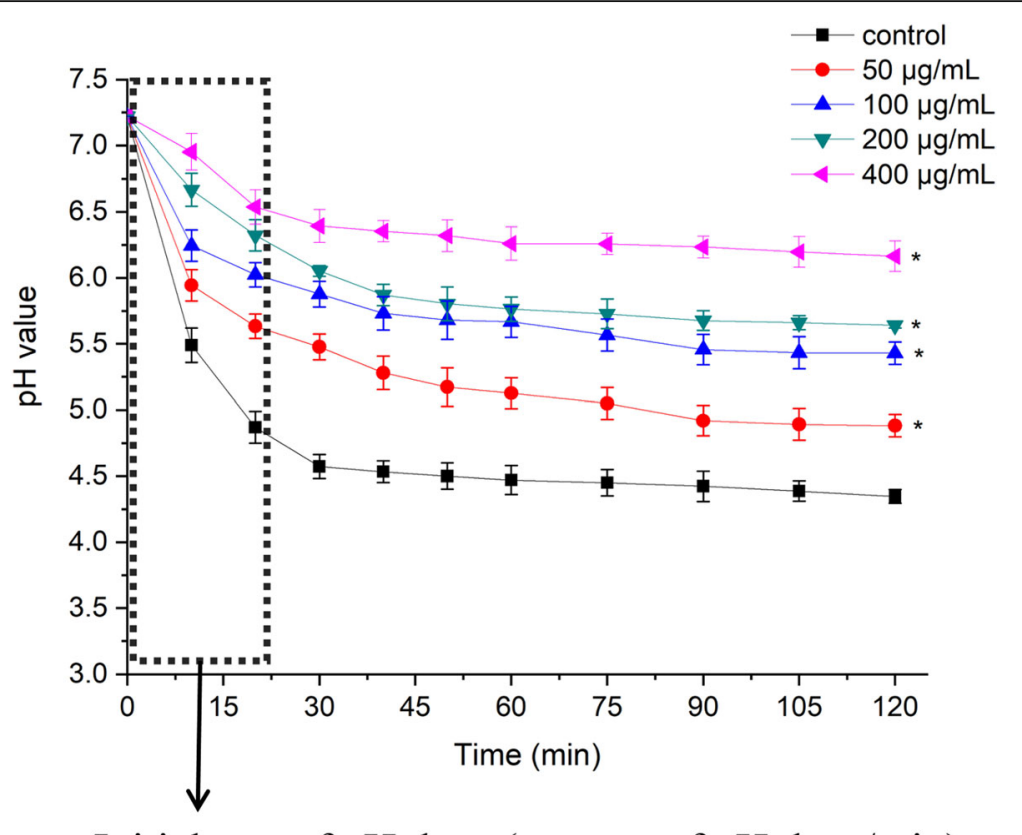

Initial rate of $\mathrm{pH}$ drop (amount of $\mathrm{pH}$ drop/min)

\begin{tabular}{ccccc}
\hline control & $50 \mu \mathrm{g} / \mathrm{mL}$ & $100 \mu \mathrm{g} / \mathrm{mL}$ & $200 \mu \mathrm{g} / \mathrm{mL}$ & $400 \mu \mathrm{g} / \mathrm{mL}$ \\
\hline 0.117 & 0.079 & 0.065 & 0.050 & 0.039
\end{tabular}

Fig. 2 Effect of resveratrol on Glycolytic pH drop. *Statistically significant differences $(P<0.05)$ between with or without resveratrol

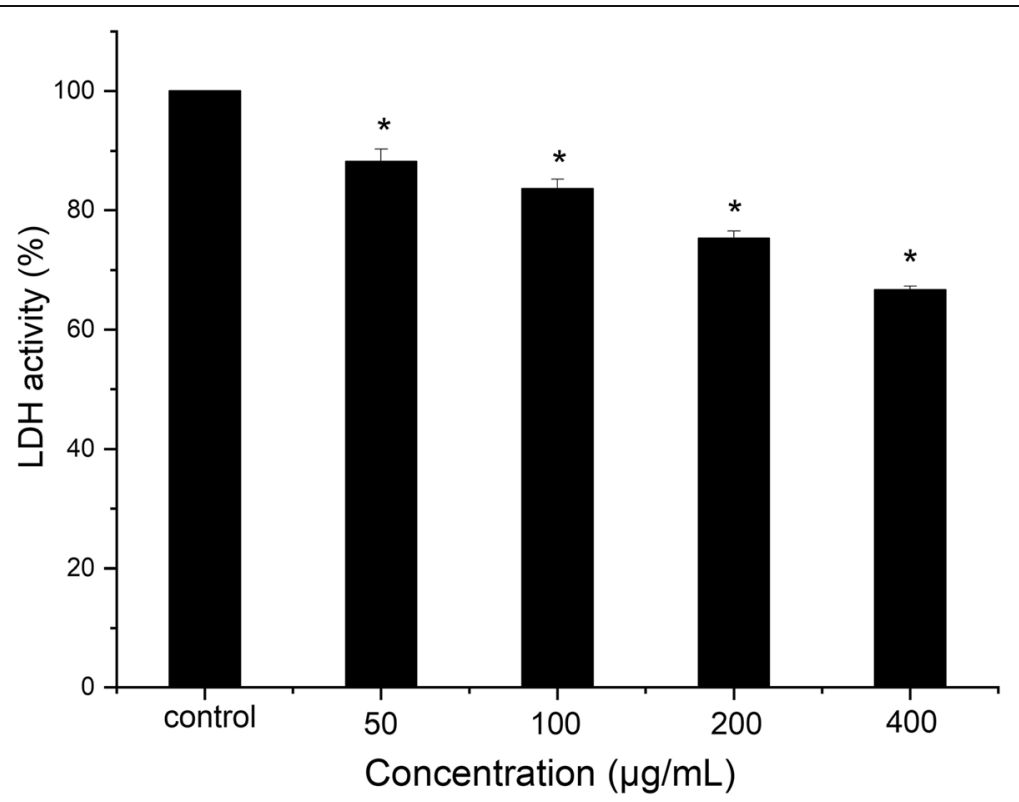

Fig. 3 Effect of resveratrol LDH activity. *Statistically significant differences $(P<0.05)$ between with or without resveratrol 

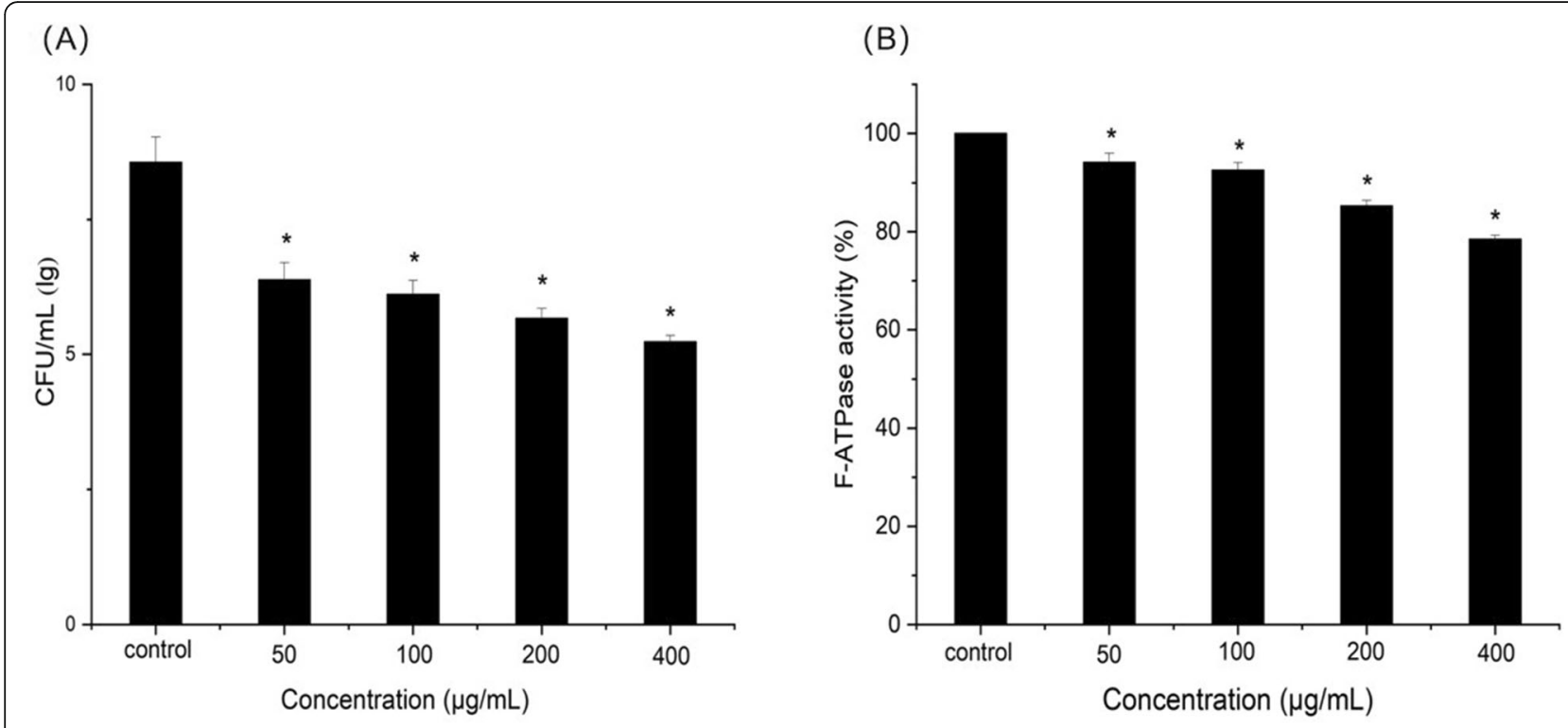

Fig. 4 Effect of resveratrol on acid production. a Survival rate of S. mutans at pH 5.0, b F-ATPase activity. *Statistically significant differences $(P<$ $0.05)$ between with or without resveratrol

treatment with resveratrol at 50,100, 200 and $400 \mu \mathrm{g} /$ $\mathrm{mL}$ compared with the control $(P<0.05)$. At the same time, F-ATPase activity assay was performed to confirm the effect of resveratrol on acid tolerance. The F-ATPase activity of $S$. mutans was decreased from $94.2 \pm 1.8 \%$ at $50 \mu \mathrm{g} / \mathrm{mL}$ to $78.5 \pm 0.8 \%$ at $400 \mu \mathrm{g} / \mathrm{mL}$ compared with the control as shown in Fig. 4b. This indicated that resveratrol had a significant inhibitory effect on FATPase compared with the control $(P<0.05)$.

\section{Polysaccharide analyses}

Polysaccharide including water-soluble polysaccharide and water-insoluble polysaccharide was measured by phenol-sulfuric acid method. The results were shown in

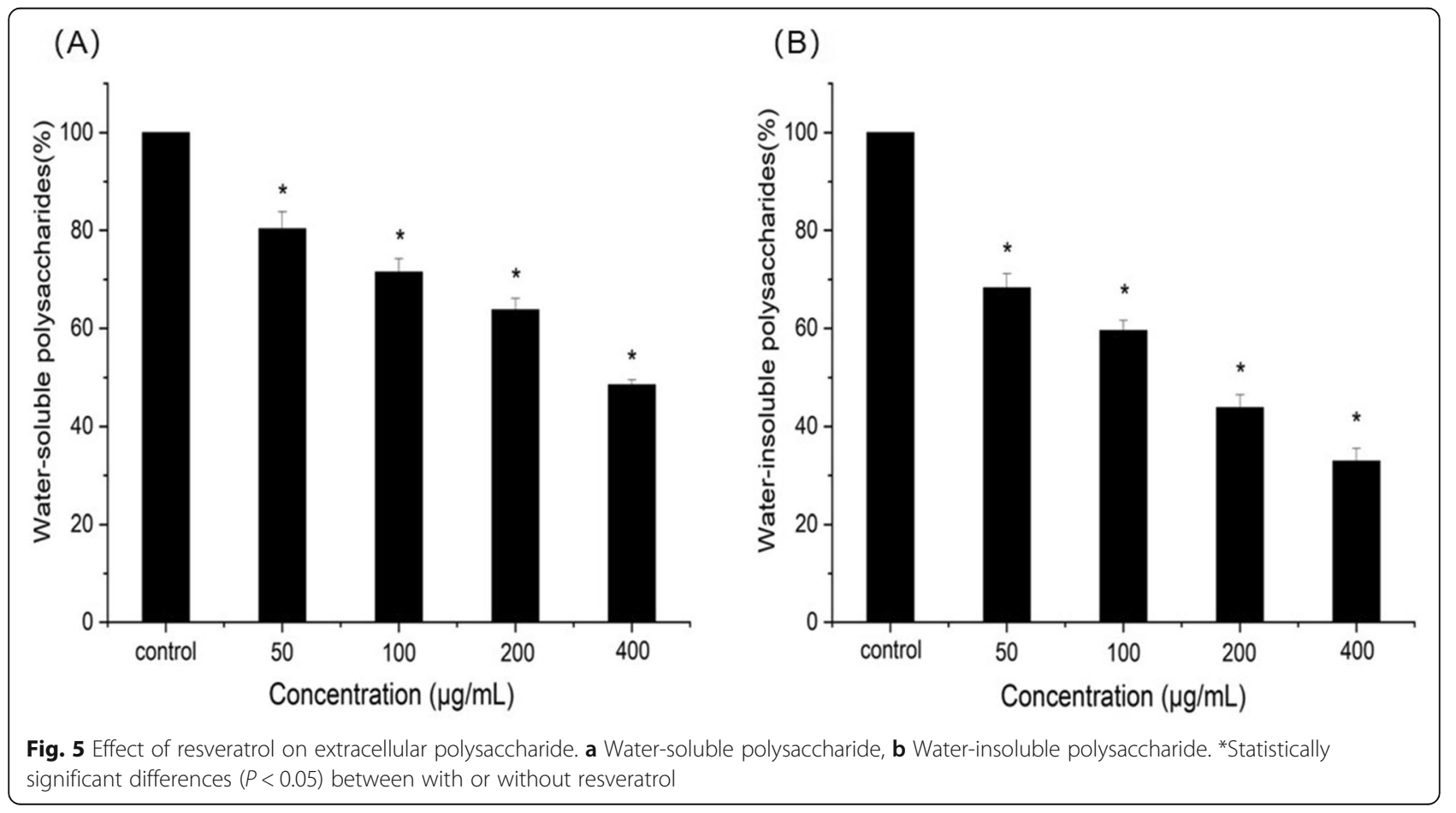


Fig. 5a and b. Compared with the control group, the water-soluble polysaccharide produced by $S$. mutans was reduced by $20-50 \%$ at different concentration of resveratrol, while the water-insoluble polysaccharide was reduced by $30-70 \%$. Resveratrol can significantly inhibit production of water-.

Soluble and water-insoluble polysaccharides compared with the control $(P<0.05)$.

\section{Biofilm biomass}

The quantification of biofilm formed by $S$. mutans with concentrations of resveratrol $(0,50,100,200,400 \mu \mathrm{g} /$ $\mathrm{mL}$ ) were shown in Fig. 6 . There were significant differences in the overall biomass of biofilms at both $6 \mathrm{~h}$ and $24 \mathrm{~h}$ time points for different concentrations of resveratrol compared with the control $(\mathrm{P}<0.05)$. After $6 \mathrm{~h}$ incubation, the OD $595 \mathrm{~nm}$ values of the biofilm formed by $S$. mutans was $1.63 \pm 0.15$. With increasing concentration of resveratrol, the OD $595 \mathrm{~nm}$ values decreased from $1.42 \pm 0.12$ at $50 \mu \mathrm{g} / \mathrm{mL}$ to $0.89 \pm 0.11$ at $400 \mu \mathrm{g} / \mathrm{mL}$. A similar trend was observed after $24 \mathrm{~h}$. The OD $595 \mathrm{~nm}$ values decreased from $3.25 \pm 0.45$ in the absence of resveratrol to $1.88 \pm 0.18$ in the presence of $400 \mu \mathrm{g} / \mathrm{mL}$ resveratrol. These results indicated that resveratrol can inhibit S. mutans biofilm formation at different time points.

\section{Biofilm structure}

The structures of the biofilms formed on glass-bottom chamber slides treatment with different concentrations of resveratrol were shown in Fig. 7. The biofilms generated by $S$. mutans without resveratrol aggregated into distinct clusters with a thick, dense structure (Fig. 7a). Following treatment with resveratrol, the biofilms appeared more looser and disperser (Fig. 7b-e). According to the CLSM images, the biofilm thickness after $24 \mathrm{~h}$ of cultivation without resveratrol was $26.69 \pm$ $1.78 \mu \mathrm{m}$. In the presence of increasing concentration of resveratrol, the biofilm thicknesses became significantly thinner $(P<0.05)$, and it was only approximately $10.37 \pm$ $0.71 \mu \mathrm{m}$ at a $400 \mu \mathrm{g} / \mathrm{mL}$ concentration of resveratrol.

\section{Gene expression}

The expression changes of four genes involved in acid production (ldh), acid tolerance (relA), extracellular polysaccharide synthesis $(g t f C)$ and biofilm formation $(c o m D E)$ in $S$. mutans treated with different concentration of resveratrol were quantified by real time RT-PCR. As shown in Fig. 8, all virulence genes tested was significantly down regulated after resveratrol treatment compared to the control group $(P<0.05)$. Expression levels in tested genes (ldh, relA, gtfC, comDE) expression levels treated with $50 \mu \mathrm{g} / \mathrm{mL}$ resveratrol were reduced 0.258 , $0.174,0.312$ and 0.413 -fold respectively. The downregulation gene expression was in a dose-dependent manner with resveratrol concentrations. Among them, expression of relA were most significantly decreased by 0.0099 -fold after $400 \mu \mathrm{g} / \mathrm{mL}$ resveratrol treatment. Expression levels in other genes $(l d h, g t f C, c o m D E)$ expression levels under $400 \mu \mathrm{g} / \mathrm{mL}$ resveratrol treatment were decreased $0.013,0.065$ and 0.119 -fold respectively.

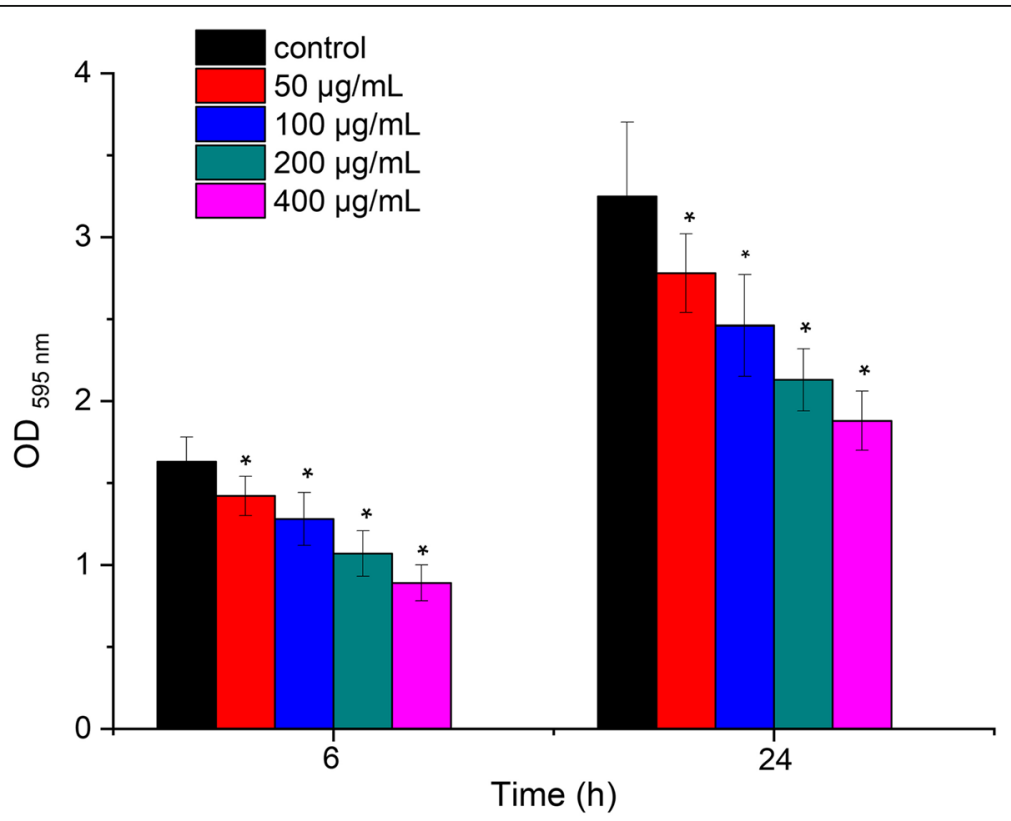

Fig. 6 Effect of resveratrol on biofilm formation at $6 \mathrm{~h}$ and $24 \mathrm{~h}$ time points. ${ }^{*}$ Statistically significant differences $(P<0.05)$ between with or without resveratrol at $6 \mathrm{~h}$ and $24 \mathrm{~h}$ time points 


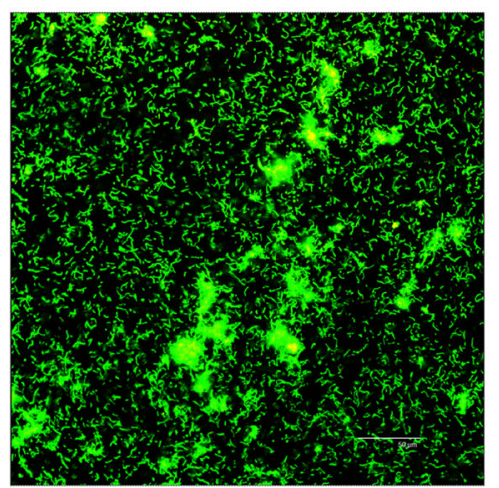

(A)

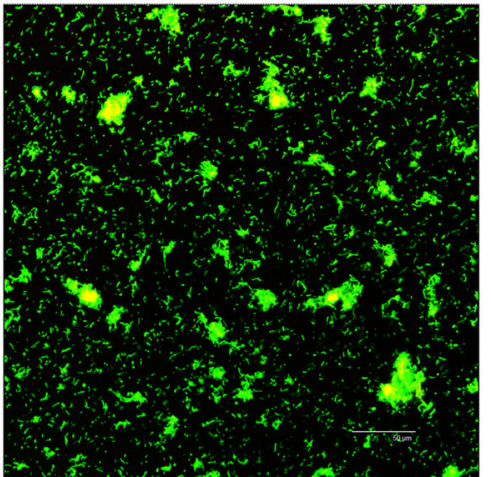

(C)

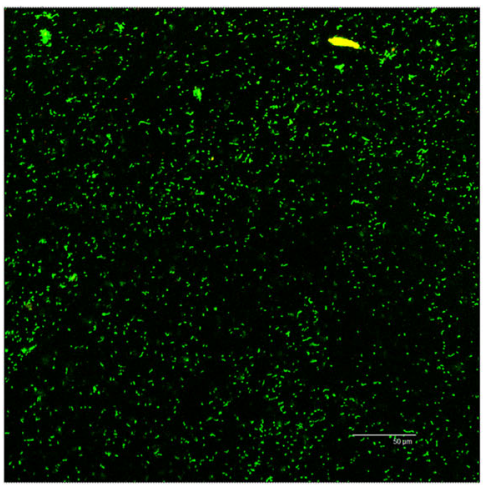

(E)

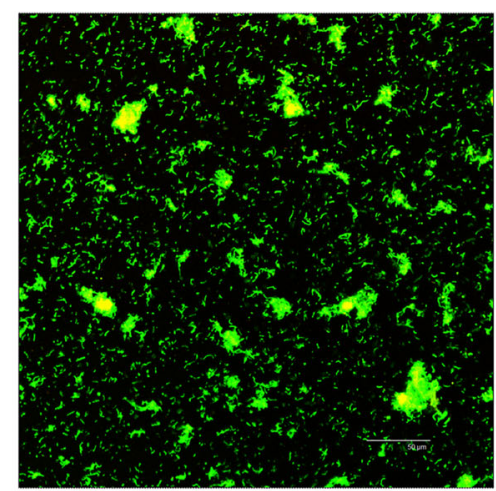

(B)

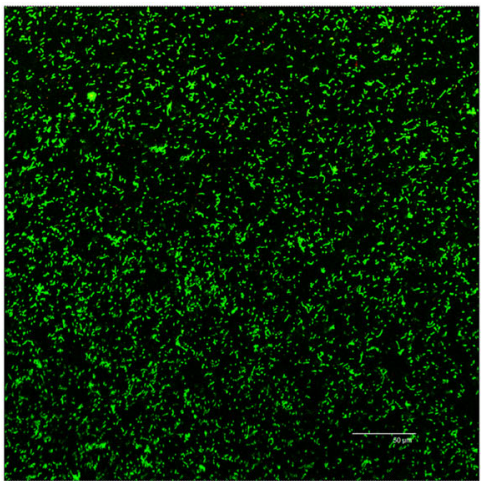

(D)

Fig. 7 Effect of resveratrol on biofilm structure by confocal laser scanning micrographs. (a) $0 \mu \mathrm{g} / \mathrm{mL}$ (b) $50 \mu \mathrm{g} / \mathrm{mL}$ (c) $100 \mu \mathrm{g} / \mathrm{mL}$ (d) $200 \mu \mathrm{g} / \mathrm{mL}$ (e) $400 \mu \mathrm{g} / \mathrm{mL}$. Bar $=50 \mu \mathrm{m}$

\section{Discussion}

Dental caries is one of the most common oral infectious disease and a major health problem affecting thousands of people worldwide. S. mutans is the primary etiological agent of dental caries. Although several antimicrobial agents are used for the prevention of dental caries, the search for an effective agent with minimal side effects is still urgent. Under this background, nature plant products have attracted great attention in recent years. Previous researches studied the effect of the substances separated from Polygonum cuspidatum root on the development of dental caries [18-20]. Among them, a fraction (F1) was mainly composed of resveratrol, emodin and physcion (approximately 16.2, 18.9 and 2.07\%, respectively). F1, alone or in combination with fluoride, has the ability to disrupt virulence factors of $S$. mutans biofilms. Another fraction F3 which consisted mainly of resveratrol and emodin (approximately 60\%) showed the strongest inhibitory effect on the acidogenicity of $S$. mutans. Since these studies were carried out on crude extracts, we investigated the effect of resveratrol on $S$. mutans anti-cariogenic properties in this article.

Cariostatic effect can be obtained through reducing the production of acid by cariogenic bacteria or 


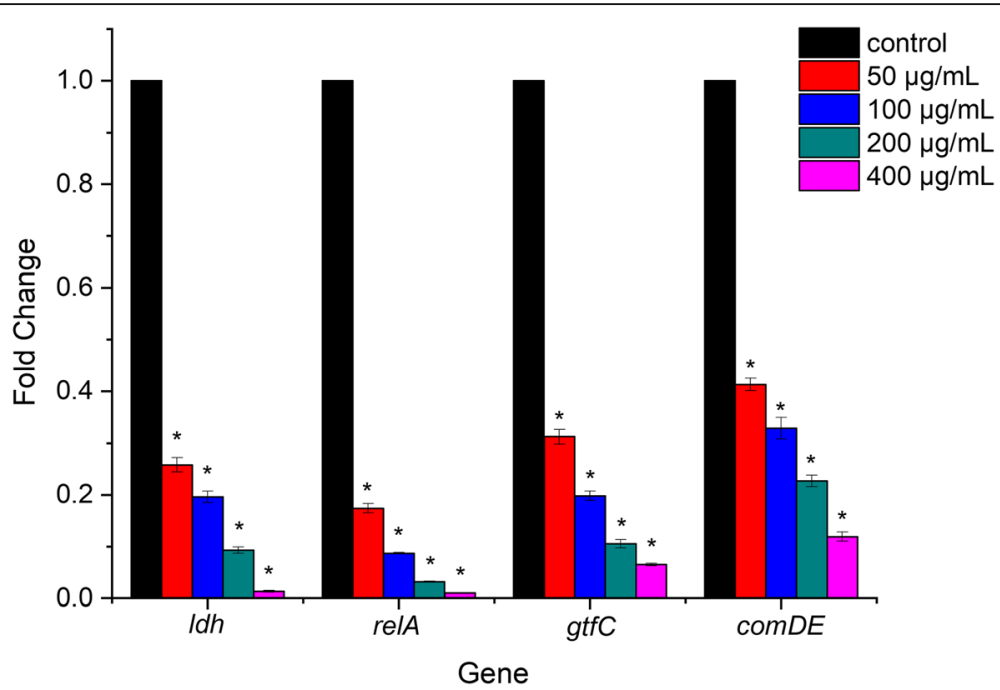

Fig. 8 Effect of resveratrol on gene expression of S.mutans biofilms. *Statistically significant differences $(P<0.05)$ in gene expression between with or without resveratrol

inhibiting the activity of enzyme associated with the glycolysing systems [21]. Glycolysis is the main pathway to produce acid, and LDH known for lactic acid production is an important enzyme in the process of $S$. mutans [22]. Therefore, this study investigated the acid production through glycolytic acid production assay and LDH activity assay. A reduction in the initial rate of $\mathrm{pH}$ drop and LDH activity with resveratrol were shown in Fig. 2 . These findings suggested that resveratrol reduced the acid production rates of $S$. mutans at sub-MIC levels due to the suppression of bacterial glycolytic pathway. Moreover, the final $\mathrm{pH}$ values in glycolytic $\mathrm{pH}$ drop assay with 200 and $400 \mu \mathrm{g} / \mathrm{mL}$ resveratrol were much higher than the critical $\mathrm{pH}$ value which balances the rate of demineralization and remineralization of tooth enamel [23]. The final $\mathrm{pH}$ values also implied acid tolerance, another key virulence property in S. mutans [24]. Our results also showed that the number of surviving $\mathrm{S}$. mutans at $\mathrm{pH} 5.0$ was significantly reduced by resveratrol. In order to confirm the inhibitory effects of resveratrol on acid tolerance, we performed protonpermeability and F-ATPase activity assays. F-ATPase maintains $\mathrm{pH}$ gradient across the cell membrane, which is related to acid tolerance [25]. The inhibition of FATPase enzymatic activity by resveratrol observed in this study may contribute to a rise in the cytoplasmic acidity, followed by decreasing acid adaptation. Thus, it is evidently that inhibitory effect of resveratrol on acid tolerance is attributed, or at least in part, to reduction of FATPase activity.

S. mutans produce water soluble and insoluble extracellular polysaccharides (EPS) which mediate the adherence and colonization in the oral cavity [26]. Furthermore, insoluble extracellular polysaccharides are particularly important for the formation and structural integrity of dental biofilm matrix [27]. In the present study, resveratrol reduced both water soluble and water insoluble polysaccharides and the reduction of insoluble polysaccharide was more significantly, which will inhibit adherence and biofilm formation. We also investigated the effect of resveratrol on biofilm formation. Biofilm formation is a complex process that begins with the initial adherence to a substrate surface, reversibly and irreversible attachment, and finally matures into integrated biological structure $[28,29]$. The results of $\mathrm{CV}$ assays showed that resveratrol reduced biofilm formation during different growth phases including initial adherence phase $(6 \mathrm{~h})$ and maturation phase $(24 \mathrm{~h})$ at sub-MIC level. This is in agreement with CLSM images that the biofilms became much looser and thinner after treatment with resveratrol. These results suggested that resveratrol can efficiently inhibit the biofilm formation not by decreasing in bacterial viability.

Additionally, we also investigated the effect of resveratrol on various cariogenic virulence factors of $S$. mutans at transcriptional levels. The expression profile of virulence genes including acid production, acid tolerance, extracellular polysaccharide synthesis and biofilm formation. Real time PCR results showed that the lactate dehydrogenase $(l d h)$ gene expression were down regulated which was consistent with the LDH activity assay. RelA gene encodes guanosine tetra (penta)-phosphatesynthetase be involved in the oxidative stress and acid tolerance mechanisms [30]. Our results found that this gene expression was reduced which impaired acid tolerance of S. mutans. GTFC (encoded by gtfC), catalyse the synthesis of water insoluble and alkali soluble glucan from sucrose with both $\alpha-1,3$ and $\alpha-1,6$-linked glucans, which are required for biofilm formation and structurally stable 
biofilms. The gtfC Mutant strains of $S$. mutans is less cariogenic than the wild type strains in vivo [31, 32]. The ComDE system is the most common intraspecific cell-cell communication quorum sensing system in $S$. mutans. The quorum sensing system is an essential component of entire gene regulation networks responsible for the adaptation of bacteria in biofilms [33, 34]. It can respond to environmental fluctuations and mediate a number of physiological virulence activities including biofilm formation. Inactivation of any component of $S$. mutans ComCDE pathway resulted in a phenotype that was biofilm-defective [35]. The repression of this gene would attenuate internal communication quorum sensing mechanism in $S$. mutans and further inhibit biofilm formation. Therefore, the reduction in the expression of tested genes will thereby suppress a series of various cariogenic virulence factors in S. mutans.

\section{Conclusions}

Resveratrol, a natural compound found in plant, has an inhibitory effect at sub-MIC level on S. mutans cariogenic virulence factors including acid production, acid tolerance, extracellular polysaccharide synthesis, biofilm formation and structure, virulence gene expression. This study has laid the foundation for resveratrol as a new natural product to inhibit the physiological activity of cariogenic bacteria and subsequently the development of dental caries. However, we have not studied its toxic effect in the oral cavity, which is very necessary before clinical application (for example, as an antibacterial ingredient in oral health-care products). Further studies will contribute to understanding the molecular mechanism for treatment and prevention of dental caries.

\section{Methods}

\section{Resveratrol, bacterial strain, and growth conditions}

Resveratrol (Sigma-Aldrich, USA) was dissolved in dimethyl sulfoxide (DMSO, Sigma-Aldrich, USA) to a stock concentration of $80 \mathrm{mg} / \mathrm{mL}$ and diluted in medium to the appropriate concentrations for each experiment. The bacterial strain S. mutans UA159 was grown in brain-heart infusion broth (BHI; Oxoid) anaerobically $\left(85 \% \mathrm{~N}_{2}, 10 \% \mathrm{H}_{2}\right.$ and $\left.5 \% \mathrm{CO}_{2}\right)$ at $37^{\circ} \mathrm{C}$ in this study. The concentration of DMSO used was up to $1 \%$ $(800 \mu \mathrm{g} / \mathrm{mL}$ in the resveratrol group), BHI broth or saline solution with $1 \%$ DMSO but without resveratrol acted as vehicle control.

\section{Growth curve assay and minimum inhibitory concentration (MIC)}

The effect of various concentrations of resveratrol on the growth of $S$. mutans was assessed by growth curve assay. Briefly, aliquots of overnight culture of $S$. mutans were diluted in $\mathrm{BHI}$ broth to the final concentration of
$1 \times 10^{7} \mathrm{CFU} / \mathrm{mL}$. Various concentrations of resveratrol $(0,50,100,200,400,800 \mu \mathrm{g} / \mathrm{mL})$ was added into BHI broth and anaerobically inoculated at $37^{\circ} \mathrm{C}$ for $24 \mathrm{~h}$. The bacterial growth was measured using spectrophotometer (UV-1750, Shimadzu, Japan) at OD600 $\mathrm{nm}$ every $3 \mathrm{~h}$ throughout $24 \mathrm{~h}$ of incubation. The growth curve assays were repeated three times independently.

\section{Glycolysis pH drop assay}

The effect of resveratrol on $S$. mutans glycolysis $\mathrm{pH}$ drop was measured according to earlier methodology [36]. Briefly, S. mutans was harvested at mid-logarithmic phase by centrifugation, washed with a salt solution (50 $\mathrm{mM} \mathrm{KCl}+1 \mathrm{mM} \mathrm{MgCl} 2$ ), and resuspended in the same salt solution containing different concentrations of resveratrol $(0,50,100,200,400 \mu \mathrm{g} / \mathrm{mL})$, The $\mathrm{pH}$ of the mixture was adjusted to 7.2 with $0.1 \mathrm{M} \mathrm{KOH}$ solution and glucose was added in the mixture to a final concentration of $1 \%(\mathrm{w} / \mathrm{v})$. The decrease in $\mathrm{pH}$ by glycolytic activity of $S$. mutans UA159 was assessed at $10 \mathrm{~min}$ intervals over a period of $120 \mathrm{~min}$. The experiments were repeated for three times independently.

\section{Lactate dehydrogenase (LDH) assay}

S. mutans cells were collected at late exponential phase and incubated at $37^{\circ} \mathrm{C}$ in Tris- $\mathrm{HCl}$ buffer ( $\left.\mathrm{pH} 7.0\right)$ con-

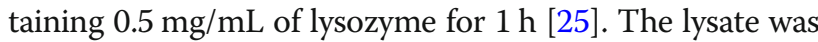
then sonicated on ice for 2 cycles of $60 \mathrm{~s}$ each, and the cell-free supernatant was collected by centrifugation for $10 \mathrm{~min}$ at $4{ }^{\circ} \mathrm{C}$. The crude extract was further dialyzed at $4{ }^{\circ} \mathrm{C}$ overnight against $10 \mathrm{mM}$ phosphate buffer ( $\mathrm{pH} 6.9$ ). The dialyzed preparation was defined as crude LDH, and its total protein concentration was measured by the Bradford method to normalize the enzyme activity.

For the LDH assay, crude LDH was pretreated with concentrations of resveratrol $(0,50,100,200,400 \mu \mathrm{g} /$ $\mathrm{mL}$ ) at room temperature for $30 \mathrm{~min}$. The reaction mixture $(200 \mu \mathrm{l})$ contained $180 \mu \mathrm{l}$ of $50 \mathrm{mM}$ phosphatebuffered saline (pH 6.9) with $0.167 \mathrm{mM} \mathrm{NADH}$ and 10 $\mathrm{mM}$ sodium pyruvate; $10 \mu \mathrm{l}$ of fructose 1,6-diphos- phate (final concentration of $1 \mathrm{mM}$ ); and $10 \mu \mathrm{l}$ of pretreated LDH.

Results were expressed as enzymatic activity relative to that of the untreated control. The experiments were performed in triplicates independently.

\section{Acid tolerance assay}

The effect of resveratrol on the acid tolerance of $S$. mutans was evaluated by measurement of the viability of bacteria after $120 \mathrm{~min}$ of exposure at $\mathrm{pH} 5.0$ [37]. S. mutans was grown in BHI medium until reaching the mid-logarithmic phase. The cells were collected by centrifugation and resuspended $\left(1 \times 10^{7} \mathrm{CFU} / \mathrm{mL}\right)$ in TYEG (10\% tryptone, $5 \%$ yeast extract, $3 \% \mathrm{~K}_{2} \mathrm{HPO}_{4}$, and $1 \%$ 
glucose medium buffered with $40 \mathrm{mM}$ phosphate-citrate buffer ( $\mathrm{pH}$ 5.0) containing different concentration of resveratrol $(0,50,100,200,400 \mu \mathrm{g} / \mathrm{mL})$. After incubation at $37^{\circ} \mathrm{C}$ for $2 \mathrm{~h}$, cells were serially diluted and plated on $\mathrm{BHI}$ agar plates for viable counts. The experiments were repeated for three times independently.

\section{F-ATPase activity}

S. mutans cells was permeabilized by subjecting the cells to $10 \%$ toluene $(\mathrm{v} / \mathrm{v})$ followed by two freezing and thawing cycles according to the method described by Belli et al [38]. The F-ATPase activity was evaluated in terms of inorganic phosphate release in the following reaction mixture: $75 \mathrm{mM}$ of Tris-maleate buffer (pH 7.0) containing $5 \mathrm{mM}$ ATP, $10 \mathrm{mM}$ of $\mathrm{MgCl}_{2}$, permeabilized cells, and different concentrations of resveratrol $(0,50,100$, $200,400 \mu \mathrm{g} / \mathrm{mL}$ ). After $30 \mathrm{~min}$ of reaction, the released phosphate was determined using the method of Bencini et al [39]. The experiments were repeated for three times independently.

\section{Polysaccharide analyses}

The extracellular polysaccharide of $S$. mutans was extracted as previously described with minor modifications [40]. S. mutans was incubated with different concentration of resveratrol $(0,50,100,200,400 \mu \mathrm{g} / \mathrm{mL})$ for $24 \mathrm{~h}$ at $37^{\circ} \mathrm{C}$. An equivalent reaction mixture without resveratrol was set as control. The reaction mixture was centrifugated at $10000 \mathrm{rpm}$ for $10 \mathrm{~min}$ to separate watersoluble polysaccharide (part 1 , supernatant) and waterinsoluble polysaccharide (part 2 , precipitate). All the supernatant (Part 1) was pooled and added three volumes of cold ethanol. After centrifugation at $4{ }^{\circ} \mathrm{C}$, the supernatant was discarded, and the precipitate (watersoluble polysaccharide) was collected and washed by cold $75 \%$ ethanol. The water-soluble polysaccharides were measured using the phenol-sulfuric acid method ( $0.1 \%$ glucose was used for the standard curve). The precipitate (part 2) was dried for $3 \mathrm{~h}$ in a Speed Vac concentrator, and used for determination of water-insoluble polysaccharides. The water-insoluble polysaccharides were extracted using $1 \mathrm{M} \mathrm{NaOH}$ with agitation at room temperature for $2 \mathrm{~h}$. The water-insoluble polysaccharides were also centrifuged, precipitated, washed and quantified as described above. The experiments were repeated for three times independently.

\section{Crystal violet assay}

Crystal violet assays was used to determine the effect of resveratrol on $S$. mutans biofilm formation in a 96-well microtiter plate [15]. Briefly, overnight culture of $S$. mutans was added into BHI broth with different concentrations of resveratrol $(0,50,100,200,400 \mu \mathrm{g} / \mathrm{mL})$. After incubation at $37^{\circ} \mathrm{C}$ for $6 \mathrm{~h}, 24 \mathrm{~h}$, the supernatants were removed and washed by sterile PBS three times. Biofilm was stained with $0.1 \%(\mathrm{w} / \mathrm{v})$ crystal violet for $5 \mathrm{~min}$ at room temperature. After washed by sterile PBS three times, $200 \mu \mathrm{l}$ of $95 \%$ ethanol was added to each crystal violet-stained well. Plates were shaken for $10 \mathrm{~min}$, and biofilm formation was quantified by measuring optical density at $595 \mathrm{~nm}$. The experiments were repeated for three times independently.

\section{Biofilm structure}

The $S$. mutans biofilms with different concentrations of resveratrol $(0,50,100,200,400 \mu \mathrm{g} / \mathrm{mL})$ were inoculated on glass slides in 6-well plates at $37^{\circ} \mathrm{C}$ to observe its structure by confocal laser scanning microscopy (CLSM). After incubation for $24 \mathrm{~h}$, the supernatants were removed, washed by sterile PBS three times and stained by the LIVE/DEAD BacLight ${ }^{\text {tw }}$ Bacterial Viability Kit for $15 \mathrm{~min}$ in the dark according to the manufacture recommendation. This Kit contains SYTO 9 which dyed live cells with intact membranes green fluorescent and propidium iodide (PI) which dyed dead cells with damaged cell membrane red fluorescence. Three random fields of each sample were imaged on a Leica SP5 confocal laser scanning microscopy.

\section{RNA isolation and real time PCR}

To analyse the effect of resveratrol on virulence genes (ldh, relA, gtfC, comDE) expression, total RNA of $S$. mutans with different concentrations of resveratrol $(0$, $50,100,200,400 \mu \mathrm{g} / \mathrm{mL}$ ) was extracted by TRIzol reagent (Sigma-Aldrich). cDNA conversion of isolated RNA was done by a cDNA synthesis kit (Takara, Dalian,

Table 1 Specific primers of quantitative real-time PCR

\begin{tabular}{|c|c|c|c|}
\hline \multirow[t]{2}{*}{ Gene $^{a}$} & \multicolumn{2}{|l|}{ Primer sequence $\left(5^{\prime}-3^{\prime}\right)$} & \multirow[t]{2}{*}{ Description } \\
\hline & Forward & Reverse & \\
\hline 165 rRNA & AGCGTTGTCCGGATTTATTG & CTACGCATTTCACCGCTACA & Normalizing internal standard \\
\hline Idh & GGCGACGCTCTTGATCTTAG & GGTTAGCAGCAACGAGGAAG & Lactate dehydrogenase \\
\hline relA & ACAAAAAGGGTATCGTCCGTACAT & AATCACGCTTGGTATTGCTAATTG & Guanosine tetra (penta)-phosphatesynthetase \\
\hline gtfC & GGITAACGTCAAAATTAGCTGTATTAGC & СTCAACCAACCGCCACTGTT & Water soluble and insoluble glucan production \\
\hline comDE & ACAATTCCTTGAGTTCCATCCAAG & TGGTCTGCTGCCTGTTGC & Competence-stimulating peptide \\
\hline
\end{tabular}

${ }^{\mathrm{a}}$ Based on the NCBI S. mutans UA159 genome database 
China) according to the manufacturer's instructions. The real-time PCR was performed in Applied Biosystems 7500 Real-Time PCR System (Applied Biosystems). All primers used are listed in Table 1 . The reaction mixture contained SYBR Green PCR Master Mix (Takara), template cDNA and forward and reverse primers. The PCR conditions included an initial denaturation at $95^{\circ} \mathrm{C}$ for $10 \mathrm{~min}$, followed by 40 cycles of denaturation at $95^{\circ} \mathrm{C}$ for $15 \mathrm{~s}$, annealing at $60^{\circ} \mathrm{C}$ for $30 \mathrm{~s}$. Relative mRNA expression were using the $\Delta \Delta \mathrm{Ct}$ method. Each experiment was performed with three independent RNA samples in triplicate.

\section{Statistical analysis}

Statistical analyses were performed using SPSS Statistics 20.0 (IBM, USA). The results for groups with or without resveratrol were statistically analyzed by one-way analysis of variance (ANOVA) with post hoc test. A Pvalues of $<0.05$ were considered statistically significant.

\section{Abbreviations \\ CLSM: Confocal laser scanning microscopy; CV: Crystal violet; EPS: Extracellular polysaccharide; GTFs: Glucosyltransferases; LDH: Lactate dehydrogenase; MIC: Minimum inhibitory concentration; S. mutans: Streptococcus mutans}

\section{Acknowledgments}

Not applicable.

\section{Authors' contributions}

JHL designed the experiment, analyzed the data and drafted this paper. TTW helped to conduct the experiment. WWP helped to collect and analysed the data. YQZ contributed to the guidance of the study, general supervision of the research, critically revised the manuscript. All of the authors have approved this article.

\section{Funding}

This work was supported by the National Natural Science Foundation of China (grant no.81700949).

\section{Availability of data and materials}

The datasets used and/or analysed during the current study available from the corresponding author on reasonable request.

\section{Ethics approval and consent to participate}

Not applicable.

\section{Consent for publication}

Not applicable.

\section{Competing interests}

The authors declare that they have no competing interests.

\section{Received: 27 August 2019 Accepted: 23 March 2020}

\section{7.}

\section{References}

1. Banas JA. Virulence properties of Streptococcus mutans. Front Biosci. 2004;9: 1267-77.

2. Smith EG, Spatafora GA. Gene regulation in S. mutans: complex control in a complex environment. J Dent Res. 2012;91(2):133-41.

3. Beighton D. The complex oral microflora of high-risk individuals and groups and its role in the caries process. Community Dent Oral Epidemiol. 2005; 33(4):248-55.
4. Zhu W, Liu S, Zhuang P, Liu J, Wang Y, Lin H. Characterization of acidtolerance-associated small RNAs in clinical isolates of Streptococcus mutans: potential biomarkers for caries prevention. Mol Med Rep. 2017;16(6):9242-50.

5. Xiao J, Klein MI, Falsetta ML, Lu B, Delahunty CM, Yates JR 3rd, Heydorn A $\mathrm{Koo} \mathrm{H}$. The exopolysaccharide matrix modulates the interaction between $3 \mathrm{D}$ architecture and virulence of a mixed-species oral biofilm. PLoS Pathog. 2012;8(4):e1002623.

6. Yang Y, Mao M, Lei L, Li M, Yin J, Ma X, Tao X, Yang Y, Hu T. Regulation of water-soluble glucan synthesis by the Streptococcus mutans dexA gene effects biofilm aggregation and cariogenic pathogenicity. Mol Oral Microbiol. 2019;34(2):51-63.

7. Featherstone JDB. Remineralization, the natural caries repair process-the need for new approaches. Adv Dent Res. 2009;21(1):4-7.

8. Pandit S, Kim HJ, Song KY, Jeon JG. Relationship between fluoride concentration and activity against virulence factors and viability of a cariogenic biofilm: in vitro study. Caries Res. 2013;47(6):539-47.

9. Guha-Chowdhury N, Iwami Y, Yamada T, Pearce El. The effect of fluorhydroxyapatite-derived fluoride on acid production by streptococci. J Dent Res. 1995:74(9):1618-24.

10. Jeng JH, Hsieh CC, Lan WH, Chang MC, Lin SK, Hahn LJ, Kuo MY. Cytotoxicity of sodium fluoride on human oral mucosal fibroblasts and its mechanisms. Cell Biol Toxicol. 1998;14(6):383-9.

11. Wen D, Liu Y, Li W, Liu H. Separation methods for antibacterial and antirheumatism agents in plant medicines. J Chromatogr B Analyt Technol Biomed Life Sci. 2004;812(1-2):101-17.

12. Newman DJ, Cragg GM, Snader KM. Natural products as sources of new drugs over the period. J Nat Prod. 2003;66(7):1022-37.

13. Hirasawa M, Takada K, Otake S. Inhibition of acid production in dental plaque bacteria by green tea catechins. Caries Res. 2006;40(3):265-70.

14. Koo H, Hayacibara MF, Schobel BD, Cury JA, Rosalen PL, Park YK, VaccaSmith AM, Bowen WH. Inhibition of Streptococcus mutans biofilm accumulation and polysaccharide production by apigenin and tt -farnesol. J Antimicrob Chemother. 2003;52(5):782-9.

15. He J, Wang S, Wu T, Cao Y, Xu X, Zhou X. Effects of ginkgoneolic acid on the growth, acidogenicity, adherence, and biofilm of Streptococcus mutans in vitro. Folia Microbiol (Praha). 2013:58(2):147-53.

16. Ferreira $S$, Domingues $F$. The antimicrobial action of resveratrol against listeria monocytogenes in food-based models and its antibiofilm properties. J Sci Food Agric. 2016;96(13):4531-5.

17. Kolouchová I, Matátková O, Paldrychová M, Kodeš Z, Kvasničková E, Sigler K, Čejková A, Šmidrkal J, Demnerová K, Masák J. Resveratrol, pterostilbene, and baicalein: plant-derived anti-biofilm agents. Folia Microbiol (Praha). 2018; 63(3):261-72.

18. Pandit S, Kim HJ, Park SH, Jeon JG. Enhancement of fluoride activity against Streptococcus mutans biofilms by a substance separated from Polygonum cuspidatum. Biofouling. 2012;28(3):279-87.

19. Kwon YR, Son KJ, Pandit S, Kim JE, Chang KW, Jeon JG. Bioactivity-guided separation of anti-acidogenic substances against Streptococcus mutans UA 159 from Polygonum cuspidatum. Oral Dis. 2010;16(2):204-9.

20. Ban SH, Kwon YR, Pandit S, Lee YS, Yi HK, Jeon JG. Effects of a bio-assay guided fraction from Polygonum cuspidatum root on the viability, acid production and glucosyltranferase of mutans streptococci. Fitoterapia. 2010; 81(1):30-4.

21. Hasan S, Danishuddin M, Adil M, Singh K, Verma PK, Khan AU. Efficacy of E. officinalis on the Cariogenic Properties of Streptococcus mutans: A Novel and Alternative Approach to Suppress Quorum-Sensing Mechanissm. PLoS One. 2012;7(7):e40319.

22. Fitzgerald RJ, Adams BO, Sandham HJ, Abhyankar S. Cariogenicity of a lactate dehydrogenase-deficient mutant of Streptococcus mutans serotype c in gnotobiotic rats. Infect Immun. 1989;57(3):823-6.

23. Dawes $\mathrm{C}$. What is the critical $\mathrm{pH}$ and why does a tooth dissolve in acid? Can Dent Assoc. 2003:69(11):722-4

24. Kuramitsu HK. Virulence factors of mutans streptococci: role of molecular genetics. Crit Rev Oral Biol Med. 1993:4(2):159-76.

25. Xu X, Zhou XD, Wu CD. The tea catechin epigallocatechin gallate suppresses cariogenic virulence factors of Streptococcus mutans. Antimicrob Agents Chemother. 2011;55(3):1229-36.

26. Pires JG, Zabini SS, Braga AS, de Cássia FR, de Andrade FB, de Oliveira RC, Magalhães AC. Hydroalcoholic extracts of Myracrodruon urundeuva all. And Qualea grandiflora Mart. Leaves on Streptococcus mutans biofilm and tooth demineralization. Arch Oral Biol. 2018;91:17-22. 
27. Koo H, Jeon JG. Naturally occurring molecules as alternative therapeutic agents against cariogenic biofilms. Adv Dent Res. 2009;21(1):63-8.

28. Stoodley P, Sauer K, Davies DG, Costerton JW. Biofilms as complex differentiated communities. Annu Rev Microbiol. 2002;56:187-209.

29. Lindsay D, von Holy A. Bacterial biofilms within the clinical setting: what healthcare professionals should know. J Hosp Infect. 2006;64(4):313-25.

30. Liu C, Worthington RJ, Melander C, Wu H. A new small molecule specifically inhibits the cariogenic bacterium Streptococcus mutans in multispecies biofilms. Antimicrob Agents Chemother. 2011;55(6):2679-87.

31. Yamashita Y, Bowen WH, Burne RA, Kuramitsu HK. Role of the Streptococcus mutans gtf genes in caries induction in the specific-pathogen-free rat model. Infect Immun. 1993;61(9):3811-7.

32. Huang X, Zhang K, Deng M, Exterkate RAM, Liu C, Zhou X, Cheng L, Ten Cate JM. Effect of arginine on the growth and biofilm formation of oral bacteria. Arch Oral Biol. 2017:82:256-62.

33. Li YH, Tian XL, Layton G, Norgaard C, Sisson G. Additive attenuation of virulence and cariogenic potential of Streptococcus mutans by simultaneous inactivation of the ComCDE quorum-sensing system and HK RR11 twocomponent regulatory system. Microbiology. 2008;154(11):3256-65.

34. Kaur $G$, Balamurugan P, Princy SA. Inhibition of the quorum sensing system (ComDE pathway) by aromatic 1,3-di-m-tolylurea (DMTU): Cariostatic effect with fluoride in Wistar rats. Front Cell Infect Microbiol. 2017;7:313.

35. Suntharalingam P, Cvitkovitch DG. Quorum sensing in streptococcal biofilm formation. Trends Microbiol. 2005;13(1):3-6.

36. Phan TN, Buckner T, Sheng J, Baldeck JD, Marquis RE. Physiologic actions of zinc related to inhibition of acid and alkaliproduction by oral streptococci in suspensions and biofilms. Oral Microbiol Immunol. 2004;19(1):31-8.

37. Svensäter G, Larsson UB, Greif EC, Cvitkovitch DG, Hamilton IR. Acid tolerance response and survival by oral bacteria. Oral Microbiol Immun. 1997;12(5):266-73.

38. Belli WA, Buckley DH, Marquis RE. Weak acid effects and fluorideinhibition of glycolysis by Streptococcus mutans GS-5. Can J Microbiol. 1995;41:785-91.

39. Bencini DA, Shanley MS, Wild JR, O'Donovan GA. New assay for enzymatic phosphate release: application to aspartate transcarbamylase and other enzymes. Anal Biochem. 1983;132(2):259-64.

40. Gulube Z, Patel M. Effect of Punica granatum on the virulence factors of cariogenic bacteria Streptococcus mutans. Microb Pathog. 2016:98:45-9.

\section{Publisher's Note}

Springer Nature remains neutral with regard to jurisdictional claims in published maps and institutional affiliations.

Ready to submit your research? Choose BMC and benefit from:

- fast, convenient online submission

- thorough peer review by experienced researchers in your field

- rapid publication on acceptance

- support for research data, including large and complex data types

- gold Open Access which fosters wider collaboration and increased citations

- maximum visibility for your research: over $100 \mathrm{M}$ website views per year

At $\mathrm{BMC}$, research is always in progress.

Learn more biomedcentral.com/submissions 